\title{
Outlook for Agriculture
}

\author{
With Special Reference to Eighth District Farm Products
}

\author{
CLIFTON B. LUTTRELL
}

\section{C}

HANGES in agricultural conditions in the Eighth Federal Reserve District generally follow the national pattern. Hence, the projections of the national pattern presented by the United States Department of Agriculture (USDA) at the National Agricultural Outlook Conference in Washington, D.C. last November, and in more recent reports, may be applied to the District. These projections are generally limited to the current crop marketing year which begins at different dates for the various crops. ${ }^{1}$

The mid-November forecast of realized net farm income in the nation for the current marketing year $(1975-76)$ is well above that of 1974-75, and the forecast of total net is larger than realized net since inventories will be increasing. Cash receipts from farm product sales are projected at $\$ 101$ billion, $\$ 10$ billion above the 1974-75 level. Since the forecasts were made, however, prices of some major commodities have declined somewhat and may, therefore, reduce returns from the forecasted levels. Although production expenses are likely to continue up, their rate of increase is expected to be less than in recent years.

\section{NATIONAL OUTLOOK}

\section{Farm Commodity Sales}

The projected increase in farm product sales this year is based on increased retmins from both crops and livestock. There was an 11 percent increase in the volume of crops harvested last fall, and slightly lower average crop prices are anticipated. The volume of livestock production for the 1975-76 marketing year is expected to be about the same as in 1974-75, but a sizable increase in average prices of livestock 1Year beginning July 1 for oats, barley, and tobacco, Angust 1
for rice and cotton; October 1 for soybeans, corn, and sorghum, products is anticipated. Most of the projected yearto-year gain in livestock product prices has already occurred, as prices rose sharply with the declining livestock output during 1975. Livestock output is expected to rise this year from the low rate of production experienced in late 1975 , and rising output will tend to offset the upward price pressure of further increases in demand.

Despite the sharp increase in production since last fall, crop prices during the 1975-76 marketing year are forecasted to average only 5 percent less than a year earlier as a result of rising foreign and domestic demand. Last summer's higher prices for livestock products provided incentive for increased livestock production and enhanced domestic demand for all types of crop feed.

\section{Expont Demand Up Sharply}

Export demand for U.S, grain crops has increased sharply this year (1975-76) as a result of crop failures in some major grain producing areas. The value of farm commodity exports during the 1975-76 marketing year is expected to total $\$ 22.7$ billion, well above the 1974-75 total of $\$ 21.6$ billion. The price of such exports is expected to average somewhat less than last year, but the volume is projected to be 15 percent larger. This is the sixth consecutive marketing year of rising dollar value of farm commodity exports. From about $\$ 5$ billion per year in the late 1960 s, the total value of such exports rose to more than $\$ 10$ billion in 1973 and to $\$ 20$ billion in 1974 . Reflecting both the sharp increase in the amount of crops harvested and an increase in export demand, the volume of exports of some major crops, including wheat and corn, is expected to exceed the $1974-75$ levels by 25 to 30 percent (Table 1). An increased volume of soybean 


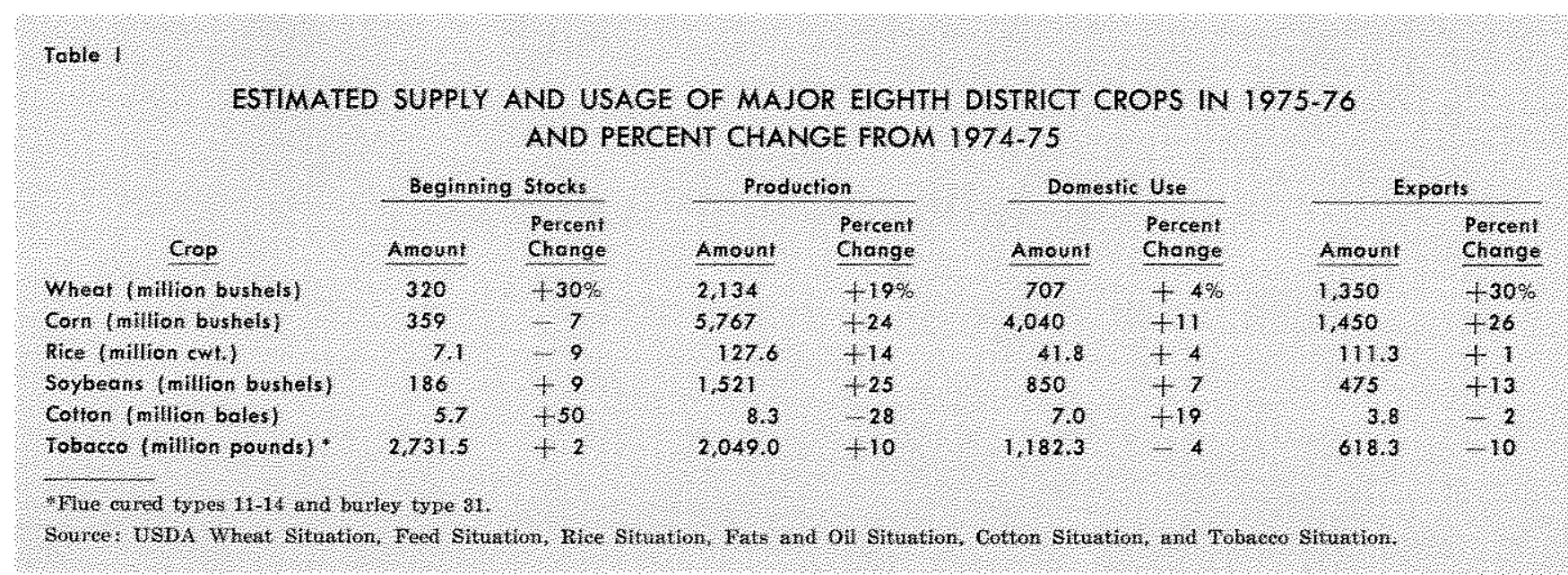

exports is anticipated, whereas rice volume may total about the same as a year ago, and cotton and tobacco shipments may decline.

Commercial sales, rather than government subsidized exports, are likely to account for most of the export increases. Sizable increases in exports of grain to the Soviet Union and Eastem Europe are indicated. The volume of farm exports to Western Europe and Latin America is expected to equal that of last year, but the dollar value of shipments to these areas may decline. Increases are projected in both volume and value of farm exports to Japan, which continues to be our largest single foreign market for farm products.

The sharp increase in Soviet demand for U.S. grain reflects both their increased livestock production of recent years and their much publicized shortfall of crops. The U.S.S.R. grain crop, estimated at $140 \mathrm{mil}-$ lion tons, was about 55 million less than a year earlier and 75 million below the original amount planned. It was the smallest grain harvest in the Soviet Union since 1965. Soviet imports of grain during the July 1975-june 1976 period are projected at 27 million metric tons, about one-half of which will be shipped from the United States. Despite these imports, the Soviets are expected to cut feed usage by about 5 percent. Substantial numbers of livestock, primarily hogs and poultry, have already been slaughtered.

The feed supply situation in Eastern Europe is somewhat less severe than that in the Soviet Union. Total grain output in these nations is down about 5 percent, and reports indicate a slowdown in livestock feeding.

The grain situation improved considerably in the less developed countries this year with production rising about 5 percent from the 1974 level. Even though this reverses a four-year deterioration in per capita output in these nations, per capita grain supplies are still only equal to those in 1973-74, and remain below the average for the 1969-71 marketing years.

\section{Produchon Expenses The at Slower Rate}

Farm production expenses in the United States are expected to continue their upward trend in 1976; however, the rate of increase will likely decline from the relatively high rates of recent years. As gross farm income rose at a relatively rapid rate, farmers bid up the price of production items. Such prices rose at an annual rate of 15 percent from 1971 to 1974 .

The variable costs for producing six major crops is projected to increase an average of 6 percent this year from the 1975 level. ${ }^{2}$ These costs rose an average of 19 percent in 1975 . The costs per unit of production will rise less than 6 percent, since higher average yields are expected.

The slower growth of farm production expenses this year largely reflects the slower rate of increase in the price of farm inputs. In contrast to the substantial price increases for most input items during the past three years, such prices are tending to level off, and the price of some will be less than a year ago. The price of fertilizer, for example, is expected to average 7 percent less (Table II). Fertilizer prices dropped sharply last summer and, with the exception of potash, now average below late 1974 levels.

Part of the increase in farm input prices since 1971 has been of a short-term nature, reflecting maladjustments caused by higher oil prices, wage-price con-

LCrops inchuded are wheat, corn, grailz sorghum, barley, soybeans, and cotton. 
trols, and some unexpectedly poor crop yields both here and abroad. The actions of the foreign oil cartel led to higher prices for both fuel and fertilizer, but unless more restrictive actions are taken, the cartel will have no further impact on farm input costs. With the reduced incentive to produce during the period of wage-price controls, production of many input items was cut back and "shortages" developed. With the removal of controls and a return to free markets, prices increased sharply to short-run equilibrium levels. Supplies of farm inputs, however, adjust more slowly than input prices as a period of time is required to increase the productive capacity for major input items. For example, the higher prices for fertilizer in 1974 eventually led to a buildup in production last year.

Some upward pressure on farm wage costs is expected to result from an increase in the Federal agricultural minimum wage rate to $\$ 2$ an hour, effective January 1, 1976. This will result in fewer workers being hired, increased unemployment, and higher per unit labor costs. Relatively high nonagricultural unemployment, however, will tend to moderate the overall increase in farm labor costs.

\section{PROSPECTS FOR MAOT

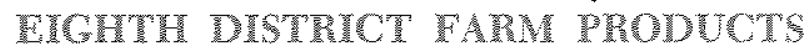

\section{Beet Cante}

With the greater incentive for cattle feeding, a return to more normal relationships between slaughter of fed and nonfed cattle is expected this year. Fed cattle slaughter has steadily declined, on a seasonally adjusted basis, since the second quarter of 1973 . By spring of 1975 such slaughter accounted for only about one-half of the total number of cattle staughtered, as compared with 80 percent two years earlier. A turnaround in the fed-nonfed cattle slaughter ratio is expected this year. The number of cattle on feed on January 1 in the 23 major feeding states was up 28 percent from a year ago pointing to a larger slaughter of fed cattle. In contrast, nonfed cattle slaughter is expected to decline as a result of the higher demand for feeder animals and the increased incentive for calf production.

Total cattle slaughter picked up in late 1974 and 1975 as feeder cattle prices declined to levels where there was no incentive for further herd increases. The price of feeder cattle for slaughter became competitive with prices of cattle moving into feedlots, and large numbers of cattle began to move to slaughter-

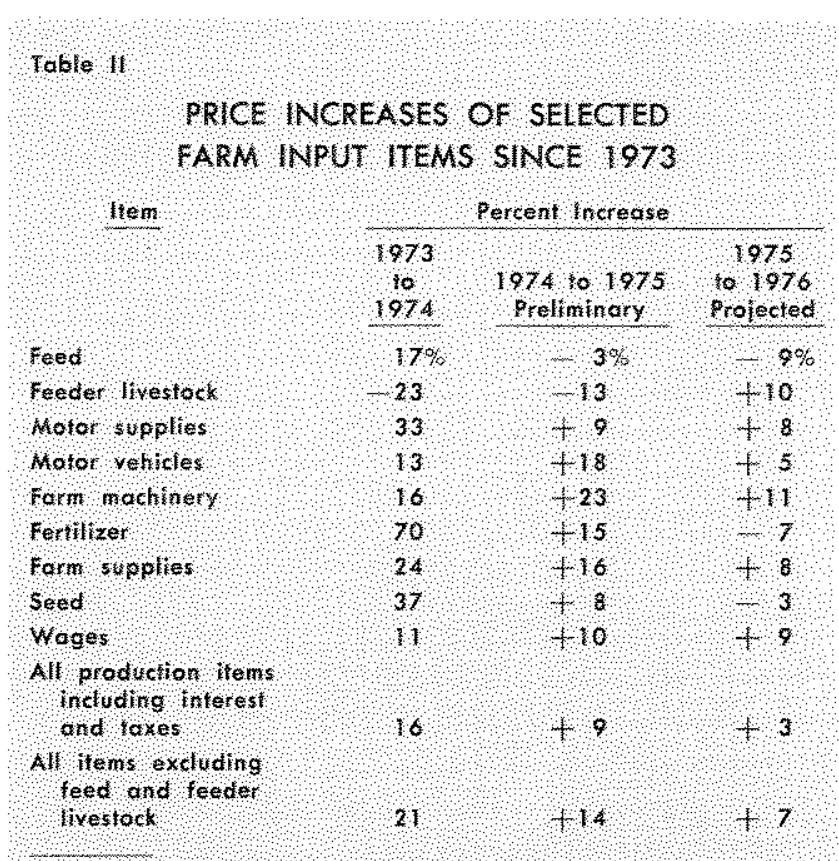

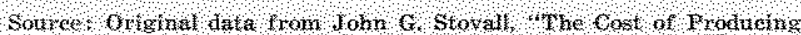

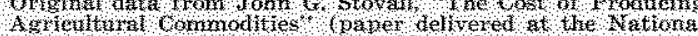

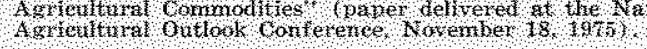

houses directly from pastures and ranges. The total number of cattle slaughtered in 1975 was about 10 percent above that of 1974, but the decline in nonfed cattle slaughter in 1976 may more than offset the increase in fed cattle slaughter, resulting in a small decline in the total. The beef cattle inventory, which had been increasing at a relatively rapid rate since the early $1970 \mathrm{~s}$, may have declined slightly last year, the first reduction in the beef cow herd since 1958 .

While beef production is expected to increase somewhat this year, demand for fed beef cattle is likely to rise, and prices may average for the year near or slightly above the 1975 average. The greater incentive for feeding will also result in an increase in demand for feeder cattle, and rising cow and feeder cattle prices from the relatively low levels of 1975. Feeder prices might again exceed fed cattle prices, rising to $\$ 40$ to $\$ 50$ per cwt. for higher grade steers on midwestem markets. This compares with prices of $\$ 25$ to $\$ 30$ per cwt. in January and February 1975.

\section{Mogs}

Hog producers have also reacted to the higher profit margins from feeding, but major increases in pork production are not likely to occur before mid-1976. Based on the number of hogs on fams last September, pork production through the first quarter of 1976 will be 10 to 15 percent below the relatively low levels of a year earlier. As a result of the sharp increase in 
farrowings beginning in the fourth quarter of 1975 , however, slaughter in the spring quarter will rise somewhat from the first quarter and will likely continue up through the year, with the total for 1976 exceeding that of 1975 by 3 to 5 percent.

Despite the upswing in hog production, pork output will remain relatively low throughout the first half of the year, as compared with recent years. Hog prices are expected to average above year-ago levels through mid-year; however, they dropped below $\$ 50$ per cwt. near yearend and are likely to move lower during the year as marketings increase.

\section{Ponthy and Eggs}

A year ago poultry producers were facing declining profits and bleak prospects for a recovery of eamings; consequently, production declined. Since then, however, the spread between feed costs and broiler prices increased, providing incentive for expanded production. Broller production is likely to be up about 10 percent in the first half of 1976 from a year earlier. Last November USDA analysts did not expect broiler prices to decline much in the first half of 1976 from the fourth quarter of 1975 with the smaller supply of red meat in prospect; but broiler prices have already dropped about 10 percent from the mid-October level. In late January such prices were only $\$ 0.02$ per pound above the year-ago level.

Turkey production in the first half of 1976, although: small relative to most recent years, will likely be substantially above that of a year earlier. Turkey prices rose steadily from last February through August as production declined and prices of other meats rose. In late October New York wholesale turkey prices averaged $\$ 0.07$ per pound above those of a year earlier, but a seasonal decline occurred near yearend. Similar to the broller situation, relatively high prices for red meat and rising consumer incomes will tend to maintain turkey demand and prices above year-ago levels during the first half of 1976.

Per capita consumption of eggs has trended downward for a decade or more reffecting consumer preference for other foods; the demand for eggs this year is not expected to reverse this trend. Several egg substitutes have been introduced which are making inroads into traditional egg markets. Egg production increased late last summer and fall, but the third quarter production was still slightly below a year earlier. Despite the relatively weak demand, production is expected to continue up in early 1976 as a result of the lower feed prices.
Egg prices began to drift below year-earlier levels late last summer, but in recent weeks they have increased and moved above year-earlier levels. Nevertheless, egg prices are likely to average near or below late 1975 levels through the first half of 1976 .

\section{Dainy Products}

Milk production has been stable during the past three years with total output ranging between 115 and 116 billion pounds each year. However, net exports have trended downward, and per capita supplies of dairy products have been about constant since 1967.

Dairy products are subject to Government price supports, and in early 1975 a substantial amount of Govenment buying occurred as market prices were below the support level. Production declined somewhat during the summer, but tumed up in October, and is expected to rise throughout 1976 because of the greater incentive for feeding. Milk prices turned up during the year, rising to an average farm price of $\$ 9.53$ per hundred pounds in October. The price of milk averaged about $\$ 8.60$ per hundred pounds in 1975, up from $\$ 8.32$ in 1974.

Milk prices will possibly show sharper-than-normal seasonal declines in early 1976, but the decline will be limited by Government price supports, and farm prices for milk are expected to average above yearearlier levels.

\section{Feed Gran}

Estimated feed grain production of 202 million tons in 1975 (about 80 percent of which was com) was 22 percent larger than a year earlier and only slightly below the record 207.7 million ton crop in 1971 . Carryover stocks last year were down to 15.8 million tons, the smallest since 1948. Hence, despite the large crop the total quantity avallable this year is only 16 percent larger than a year ago. The growth in domestic demand, however, will be held in check by the relatively small number of grain consuming animals on farms. By yearend, stocks of feed grains were 21 percent above the relatively low year-earlier levels. Nevertheless, domestic use of corn is expected to rise 11 percent from the 1974-75 level (Table 1).

Export demand for feed grain is relatively strong. As indicated earlier, the drought in the Soviet Union will result in major increases in exports to that nation. Total corn exports are projected at 1.4 to 1.5 billion bushels, compared with 1.15 billion a year ago. Sor- 
ghum grain exports of 250 to 300 million bushels are projected, well above the 212 million of a year ago. Oats and barley exports are also expected to increase.

Given the projected supply and demand situation, corn prices at the farm are forecasted to average about $\$ 2.60$ per bushel during the 1975-76 marketing year. Prices of the other feed grains will tend to move with corn prices. Based on a January 1, 1976, survey of growers, acreage planted to feed grains will be increased again in 1976. Farmers reported intentions to increase corn acreage 4 percent, sorghum 2 percent, and oats 1 percent.

\section{Soyberish}

Large carryover stocks last year and a near record crop boosted the quantity of soybeans available for the year to a new high, 23 percent above the year-ago level. The harvest last fall was 25 percent larger than a year earlier, and carryover stocks were 9 percent larger (Table I). Although domestic soybean use plus exports is expected to continue moving upward, rising to 1.3 billion bushels, this may be the third consecutive year in which total utilization is less than production. By yearend soybean stocks were 26 percent above the January 1, 1975 level, and stocks at the end of the marketing year on October 1 are projected at 375 million bushels - double last year's carryover.

Reflecting the larger supply, prices received by farmers for soybeans last fall averaged less than $\$ 5$ per bushel, compared with $\$ 8$ a year earlier. Prices may increase somewhat during the year, but the season average price is expected to fall sharply below the $\$ 6.50$ per bushel of $1974-75$. Reflecting the relatively low price for soybeans, farmers reported intentions to reduce the acreage planted to soybeans this year by 7 percent.

\section{Cothon}

The trend in usage of U.S cotton has been declining. Thus, while production last fall was down 20 percent from a year earlier, carryover stocks were up, and the total available for the year is down only moderately. Production declined to 8.3 million bales from 11.5 million in 1974 , but carryover stocks were up almost 2 million bales, resulting in production plus carryover of 14.1 million bales (Table I). This is the second smallest quantity of cotton available for any year since the early $1930 \mathrm{~s}$.

Domestic consumption plus exports declined from an average of 13.8 million bales during the five years $1960-64$ to 12.5 million in $1965-69$, and to 12.1 million in 1970-74. Domestic use of cotton declined faster than exports, dropping 15 percent from 1960-64 to 1970-74, while exports dropped 12 percent.

The major factors contributing to this decline were the rising competition in the fiber market from both manmade fibers and cotton production abroad. Per capita consumption of manmade fibers in the United States rose almost four-fold from 1960 to 1974 , whereas per capita consumption of cotton declined about 33 percent. Cotton production in the foreign noncommunist countries rose from 22 million bales in 1962 to more than 28 million in 1974, somewhat faster than cotton usage grew in these nations during the period.

Domestic demand for all fiber is strengthening somewhat this year, however, and mill consumption of cotton is projected to rise. Exports, however, may be down slightly because U.S. cotton prices have been above prices of foreign competitive cotton for about a year. As a result, numerous export contracts were cancelled by foreign purchasers, and a sharp decline in shipments occurred. However, some recovery in foreign cotton prices is expected in early 1976, and U.S. cotton exports for the year may be only slightly below the 1974-75 level.

Reflecting the prospects for a relatively small 1975 crop, cotton prices rose sharply from January to September last year and are now above those of domestic competitive manmade fibers. This slight price disadvantage for cotton, however, is not considered a major factor in domestic cotton consumption for the year. The higher cotton prices have provided incentive for increased cotton acreage. In January farmers reported intentions to increase their acreage of upland cotton by 17 percent this year.

\section{Pice}

The main features in the outlook for rice are the currently large domestic supplies and a continuing growth of demand. The estimated 1975 rice crop of 128 million cwt. was 14 percent larger than the previous record crop in 1974. Carryover stocks at the close of the 1974-75 marketing year were 7 million cwt., slightly less than a year ealier, resulting in a total supply of 135 million cwt. - about 12 percent above the quantity available a year ago. However, rice shipments this year have been relatively slow, and on January 1 stocks of rice were about 32 percent above year-earlier levels.

Demand for rice, however, is expected to continue upward for the year. Domestic use has increased 
about two percent per year in recent years, and a similar rise is expected this year. Exports are expected to remain at last year's relatively high level. Exports to the Mid.East rose sharply last year to 15.5 million cwt, refecting the enhanced oil revenues of OPEC (Organization of Petroleum Exporting Countries). A high level of exports to these nations is expected again this year. Larger commercial sales to the U.S.S.R. and larger shipments through Government aid to Bangladesh are also in prospect. The generally larger world rice crop, however, may result in smaller shipments to some traditional commercial markets.

The season average price for rice is likely to fall short of last year's $\$ 10.45$ per cwt. Prices to farmers averaged $\$ 8.29$ in mid-December, down from $\$ 9.80$ in Augast. Some increase in price may occur during the marketing season, but the increase is not likely to be as great as a year ago.

\section{Tobacco}

The tobacco outlook is highlighted by increasing supplies both in the United States and abroad. U.S. tobaceo production in 1975 was about 10 percent more than a year earlier, and the total amount available is up about 5 percent. The quantity of burley tobacco (the maior type grown in the Eighth District) available for domestic use plus expont this year is up about 3 percent from the year-ago level. Burley usage was down last year, but may increase this year with the somewhat larger amount available. Carry. over stocks at the close of the year are expected to be about the same as a year ago.

Burley production is subject to government acreage controls, marketing quotas, and price supports. The legal formula requires that price supports go up about 13.5 percent this year. The marketing quota is expected to be maintained at about 667 million pounds.

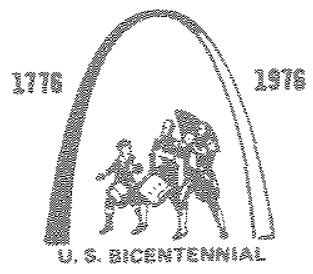

